Note

\title{
OCCURRENCE OF DIAZOTROPHIC BACTERIA IN Araucaria angustifolia
}

\author{
Rafaela de Fátima Neroni ${ }^{1}$; Elke Jurandy Bran Nogueira Cardoso ${ }^{2 *}$ \\ ${ }_{2}^{1}$ USP/ESALQ - Programa de Pós-Graduação em Solos e Nutrição de Plantas. \\ ${ }^{2}$ USP/ESALQ - Depto. de Ciência do Solo, Lab. de Microbiologia do Solo, C.P. 9 - 13418-900 - Piracicaba, SP - \\ Brasil. \\ *Corresponding author <ejbncard@esalq.usp.br>
}

\begin{abstract}
Araucaria angustifolia is an environmentally threatened tree and the whole biota of the Araucaria Forest should be investigated with the aim of its preservation. Diazotrophic bacteria are extremely important for the maintenance of ecosystems, but they have never been studied in Araucaria Forests. In this study, diazotrophic bacteria were isolated from Araucaria roots and soil, when grown in semi-specific, semi-solid media. The diazotrophic character of some recovered isolates could be confirmed using the acetylene reduction assay. According to their $16 \mathrm{~S}$ rRNA sequences, most of these isolates belong to the genus Burkholderia.
\end{abstract}

Key words: biological nitrogen fixation, endophytic bacteria, rhizosphere, forest

\section{OCORRÊNCIA DE BACTÉRIAS DIAZOTRÓFICAS EM Araucaria angustifolia}

\begin{abstract}
RESUMO: Araucaria angustifolia é uma espécie arbórea ameaçada de extinção e toda a comunidade viva das Florestas de Araucária deve ser estudada com a finalidade de sua preservação. Bactérias diazotróficas apresentam grande importância para a manutenção de ecossistemas, mas sua ocorrência nunca foi pesquisada em araucária. Neste estudo foi demonstrada a associação de bactérias fixadoras de nitrogênio com $A$. angustifolia. Amostras de solo e raízes de araucária apresentaram a ocorrência de bactérias diazotróficas, quando inoculadas em meios semi-sólidos semi-específícos. O caráter diazotrófico de alguns isolados recuperados foi confirmado através da análise de redução do acetileno. De acordo com a análise das seqüências do 16S rRNA, estes isolados são na sua maioria pertencentes ao gênero Burkholderia. Palavras-chave: fixação biológica de nitrogênio, bactérias endofíticas, rizosfera, floresta
\end{abstract}

Araucaria angustifolia (Bertol.) Kuntze is a characteristic species of forests predominant in southern Brazil. In the State of São Paulo, this conifer is concentrated in a few regions where low temperatures prevail, the region of Campos do Jordão being one of the last refuges for this species in the state. In view of the predatory wood exploitation, A. angustifolia has been included in the official list of Brazilian species under the threat of extinction (Brasil, 1992). Since there are only $3 \%$ of the original Araucaria Forests left in the country, this fact should raise our concern over the impending important loss of our genetic heritage in diversity of the microbial community associated with this species.

Diazotrophic microorganisms can perform an important role in the rehabilitation and sustainability of different ecosystems, since they incorporate nitrogen through biological fixation and produce and release substances that regulate plant growth, such as auxins, gibberellins, and cytokinins (Bazzicalupo \& Okon, 2000).

In spite of the potential importance of diazotrophic bacteria in forest ecosystems, there are no reports on studies of these microorganisms in Araucaria Forests. To isolate diazotrophic bacteria from Araucaria environments this study chose the Campos do Jordão State Park, SP, Brazil ( $22^{\circ} 44^{\prime}$ S; $45^{\circ} 27^{\prime} \mathrm{W}$ ), which had undergone different levels of anthropogenic interference. In order to isolate the diazotrophic bacteria, nine soil samples $(0-0.2 \mathrm{~m}$ layer) and nine Araucaria root samples were collected around different trees. Samples were placed in plastic bags and introduced in styrofoam containers with ice, and sent to the laboratory within 24 hours. Root samples were subjected to surface disinfection with chloramine-T at $1 \%$ for 15 minutes (Döbereiner et al., 1995). They were then washed in sterile water for five minutes and transferred to a phosphate buffer 
$0.05 \mathrm{~mol} \mathrm{~L}^{-1}$ (pH 7.0) solution. Finally, they were washed again in sterile water.

The isolation of the bacteria was based on the techniques described by Döbereiner et al. (1995). The disinfected roots $(10 \mathrm{~g})$ were crushed in a blender with $90 \mathrm{~mL}$ of saline solution for one minute and the soil samples $(10 \mathrm{~g})$ were homogenized in $90 \mathrm{~mL}$ of saline solution for 20 minutes. All samples were serially diluted, and $0.1 \mathrm{~mL}$ aliquots were placed in vials containing $5 \mathrm{~mL}$ of $\mathrm{N}$-free semisolid JNFb, LGI and $\mathrm{NFb}$ media and incubated at $28^{\circ} \mathrm{C}$ for six days. Vials showing a fine subsurface pellicle were transferred to fresh semisolid JNFb, LGI and NFb media and new growth streaked out on agar plates with the same media containing yeast extract $\left(20 \mathrm{mg} \mathrm{L}^{-1}\right)$. Colonies formed were again inoculated into new semisolid JNFb, LGI and $\mathrm{NFb}$ media and new growth streaked out on potato dextrose agar (PDA) plates. Colonies were purified and assayed for nitrogenase activity by the acetylene reduction activity (ARA) method (Burris, 1972).

Bacteria were found to grow in all three culture media, for soil and the root samples. Some of the recovered isolates had $\mathrm{N}_{2}$-fixing ability demonstrated by the acetylene reduction assay. The search for similarity in the National Center for Biotechnology Information (NCBI) GenBank (http://www.ncbi.nlm. nih.gov/BLAST), after partial sequencing of the $16 \mathrm{~S}$ rRNA genes of acetylene-reducing isolates, allowed to identify them as mostly belonging to the genus Burkholderia.

To conclusively demonstrate the endophytic characteristic of a bacterium, it is necessary to use a technique to identify them in situ, a task that is planned for the near future. Nevertheless, so far a lot of evidence in favor of this hypothesis was already accumulated. But even if the bacteria should not be endophytic, presenting only rhizospheric growth, their importance in association with Araucaria roots should not be overlooked (Gyaneshwar et al., 2002). This fact may have a great ecological and practical implication in the preservation and restauration of Araucaria Forests.

This is the first report on diazotrophic bacteria associated with $A$. angustifolia in Brazil.

\section{ACKNOWLEDGEMENTS}

To Leandro H. G. Tizato, Luis Fernando Baldesin and Denise L. C. Mescolotti for technical assistance and to Dilmar Baretta and Daniel R. Lammel for discussions. This study is a part of the project "BIODIVERSIDADE VEGETAL E DE ORGANISMOS EDÁFICOS EM ECOSSISTEMAS DE Araucaria angustifolia NATURAIS E IMPACTADOS NO ESTADO DE SÃO PAULO, Projeto Temático 01/05146-6" in the Biota Program / Fapesp. Elke J. B. N. Cardoso and Rafaela F. Neroni acknowledge respectively $\mathrm{CNPq}$ and FAPESP for a research grant.

\section{REFERENCES}

BAZZICALUPO, M.; OKON, Y. Associative and endophytic symbiosis. In: PEDROSA, F.; HUNGRIA, M.; YATES, M.G.; NEWTON, W.E. (Ed.). Nitrogen fixation: from molecules to crop productivity. Dodrecht: Kluwer Academic Publishers, 2000. p.409-410.

BRASIL. Portaria $n^{\circ} 06-\mathrm{N}$, de 15 de janeiro de 1992. Lista oficial de espécies da flora brasileira ameaçadas de extinção. Diário Oficial da República Federativa do Brasil, Brasília, 23 jan. 1992. p.870872.

BURRIS, R.H. Nitrogen fixation assay-methods and techniques. Methods in Enzymology, v.24B, p.415-431, 1972.

DÖBEREINER, J.; BALDANI, J.I.; BALDANI, V.L.D. Como isolar e identificar bactérias diazotróficas de plantas não leguminosas. Brasília: EMBRAPA, SPI.; Itaguaí: EMBRAPA, CNPAB, 1995. 60p.

GYANESHWAR, P.; JAMES, E.K.; REDDY, P.M.; LADHA, J.K. Herbaspirillum colonization increases growth and nitrogen accumulation in aluminum tolerant rice varieties. New Phytologist, v.154, p.131-146, 2002.

Received February 02, 2007

Accepted March 23, 2007 